Article

\title{
The Influence of Zeolite (Sokyrnytsya Deposit) on the Physical and Chemical Resistance of a Magnesium Potassium Phosphate Compound for the Immobilization of High-Level Waste
}

\author{
Svetlana A. Kulikova * and Sergey E. Vinokurov \\ Vernadsky Institute of Geochemistry and Analytical Chemistry, Russian Academy of Sciences, 19 Kosygin st., \\ Moscow 119991, Russia; vinokurov.geokhi@gmail.com \\ * Correspondence: kulikova.sveta92@mail.ru; Tel.: +7-495-939-7007
}

Academic Editor: Susana Valencia

Received: 15 August 2019; Accepted: 19 September 2019; Published: 20 September 2019

\begin{abstract}
The manuscript presents the results of the development of new material for high-level waste (HLW) management: the magnesium potassium phosphate (MKP) compound. The possibility of using zeolite (Sokyrnytsya deposit) to increase the mechanical, thermal, and hydrolytic resistance of this compound with immobilized HLW was studied. The main component of the used natural zeolite is a mineral of the clinoptilolite-heulandite series, and quartz, microcline, and clay minerals (illite, sepiolite, and smectite) are present as impurities. The compressive strength of the compound, containing at least $4.2 \mathrm{wt} \%$ zeolite, is about $25 \mathrm{MPa}$. Compound containing $28.6 \mathrm{wt} \%$ zeolite retains high compressive strength (at least $9.0 \mathrm{MPa}$ ), even after heat treatment at $450{ }^{\circ} \mathrm{C}$. The adding of zeolite to the composition of the compound increases its hydrolytic stability, while the leaching rate of the mobile nuclides ${ }^{137} \mathrm{Cs}$ and ${ }^{90} \mathrm{Sr}$ decreases up to one order of values. Differential leaching rate of radionuclides from the compound containing $28.6 \mathrm{wt} \%$ zeolite is $2.6 \times 10^{-7}$ for ${ }^{137} \mathrm{Cs}, 2.9 \times 10^{-6}$ for ${ }^{90} \mathrm{Sr}, 1.7 \times 10^{-9}$ for ${ }^{239} \mathrm{Pu}$, and $2.9 \times 10^{-9} \mathrm{~g} /\left(\mathrm{cm}^{2}\right.$.day) for ${ }^{241} \mathrm{Am}$. Thus, the properties of the resulting compound correspond to the requirements for solidified HLW in Russia.
\end{abstract}

Keywords: zeolite; magnesium potassium phosphate compound; cesium; strontium; plutonium; americium; immobilization; compressive strength; leaching

\section{Introduction}

The nuclear fuel cycle is the main source of radioactive waste (RW) and produces all types of it, including high-level waste (HLW). HLW is formed as a result of reprocessing of spent nuclear fuel (SNF) from reactor plants, and consists of fuel components residue $(\mathrm{U}, \mathrm{Pu})$, minor actinides (Am and $\mathrm{Cm}$ isotopes), fission products (Cs, $\mathrm{Sr}$, etc.), corrosion products ( $\mathrm{Fe}, \mathrm{Cr}, \mathrm{Al}, \mathrm{Mo}, \mathrm{Ni}, \mathrm{Zr}$, etc.) and process contaminants ( $\mathrm{Na}, \mathrm{K}, \mathrm{Ca}, \mathrm{Mg}$, etc.). According to the concept developed by the International Atomic Energy Agency, RW of any activity level must be immobilized - that is, transformed into a waste form by solidification, embedding, or encapsulating [1].

Vitrification is the only industrial technology for HLW management [2]. The use of the magnesium potassium phosphate (MKP) compound based on the $\mathrm{MgKPO}_{4} \times 6 \mathrm{H}_{2} \mathrm{O}$ matrix has particular interest as an alternative to aluminophosphate or borosilicate glass. Unlike glass, the MKP compound is a mineral-like material (K-struvite) [3], forming at room temperature and atmospheric pressure [4]. The influence of different HLW types on the properties of the MKP compound was studied, including ${ }^{99} \mathrm{Tc}$ waste solutions [5], Pu contaminated ash [6], surrogate denitrated HLW from the PUREX process [7], and HLW bottom sediment surrogates [8]. In our early works, we confirmed the premise of using the MKP compound for HLW solidification of various composition and origin, including historical 
waste from the implementation of military programs of the Soviet Union and the United States [9,10], as well as waste obtained after the reprocessing of SNF of a $1000 \mathrm{MW}$ water-water energetic reactor (WWER-1000) [11-13].

The main quality indicators of matrix materials for HLW conditioning are mechanical, thermal, and hydrolytic stability [14]. Thermal stability is required for possible significant heating (up to $300-400^{\circ} \mathrm{C}$ ) of the compound, due to heat release of radionuclides of HLW, and is assessed by the mechanical strength of the compounds after heat treatment. Hydrolytic stability is estimated by the leaching rate of radionuclides $\left({ }^{137} \mathrm{Cs},{ }^{90} \mathrm{Sr},{ }^{239} \mathrm{Pu}\right)$ from the compounds. The activity of HLW is mainly determined by the isotopes of cesium $\left({ }^{134} \mathrm{Cs},{ }^{137} \mathrm{Cs}\right)$, which is an alkali metal and, therefore, the most leached from the matrix materials. It is known that to reduce the leaching of Cs isotopes from matrices, radionuclides are converted to insoluble compounds (for example, as part of nickel-cesium ferrocyanide [12]) or exposed by sorption on specially selected sorbents (based on clinoptilolite [15-18] and clay minerals $[19,20])$. Inorganic sorbents based on transition metal ferrocyanides are unstable in alkaline media at pH 10 [1] and elevated temperatures.

It was previously noted that increasing the temperature of the MKP compound may lead to a decrease of its stability [12,13]. Zeolite is a promising mineral modifier of the MKP compound. Zeolites are porous, hydrated aluminosilicates with a general formula of $\mathrm{M}_{\mathrm{x} / \mathrm{m}}\left[\left(\mathrm{AlO}_{2}\right)_{\mathrm{x}}\left(\mathrm{SiO}_{2 \mathrm{y}}\right)\right]$, where $\mathrm{M}_{\mathrm{x} / \mathrm{m}}$ designates an ion-exchangeable cation [21]. Zeolites are the preferred inorganic ion exchange materials for radionuclide (especially cesium) concentrations from liquid RW, because of their radiation stability, high selectivity, and cation exchange capacity [22,23]. They can be incorporated into matrices (for example, cement $[19,24]$ and glass $[25,26])$ ensuring a higher degree of radionuclide retention [1]. However, in the literature, there are no data on the effectiveness of the zeolite in the MKP compound in the HLW immobilization.

In this work, we study the influence of zeolite on the physical and chemical properties of the MKP compound, in order to provide the mechanical, thermal, and hydrolytic resistance required for solidified HLW.

\section{Results and Discussion}

\subsection{Mineral and Chemical Composition of Zeolite}

The obtained data on the study of the mineral and chemical composition of the zeolite samples are given in Figure 1 and Table 1, respectively. Zeolites (clinoptillolite and heulandite) were identified by a series of basic reflexes $(9.02 \AA, 7.95 \AA, 6.79 \AA, 5.95 \AA, 5.25 \AA, 5.13 \AA, 4.66 \AA, 3.97 \AA$, etc.), quartz $(4.26 \AA$, $3.35 \AA, 2.46 \AA, 2.29 \AA, 2.13 \AA, 1.82 \AA, 1.54 \AA)$, microcline (4.26 $\AA$, $3.78 \AA$, etc.), illite (10.06 $⿱$ $2.53 \AA$, etc.), sepiolite (11.91 $\AA$ ) and smectite (14.50 $\AA$ ) (Figure 1$)$. It was established that the main component of the used zeolite is a mineral of the clinoptilolite-heulandite series (74\%), which is consistent with the data that deposits of zeolite tuff in this region are characterized by clinoptilolite content from $60 \%$ to $75 \%[27,28]$. Quartz $(12.0 \%)$, microcline $(2.0 \%)$, and clay minerals-illite $(5.0 \%)$, sepiolite $(5.0 \%)$, and smectite $(2.0 \%)$-are present in the rock as impurities. According to the results of X-ray fluorescence analysis, it was determined that the sample consists of silicon and aluminum oxides; the content of $\mathrm{SiO}_{2}$ and $\mathrm{Al}_{2} \mathrm{O}_{3}$ is 78.165 and $11.530 \mathrm{wt} \%$ (Table 1), respectively. Oxides of $\mathrm{Na}, \mathrm{K}, \mathrm{Mg}, \mathrm{Ca}, \mathrm{Fe}$, and $\mathrm{Ti}$ are also present, and $\mathrm{SrO}, \mathrm{MnO}, \mathrm{P}_{2} \mathrm{O}_{5}, \mathrm{Rb}_{2} \mathrm{O}, \mathrm{BaO}, \mathrm{ZrO}_{2}$, and $\mathrm{Y}_{2} \mathrm{O}_{3}$ were found as micro-impurities. 


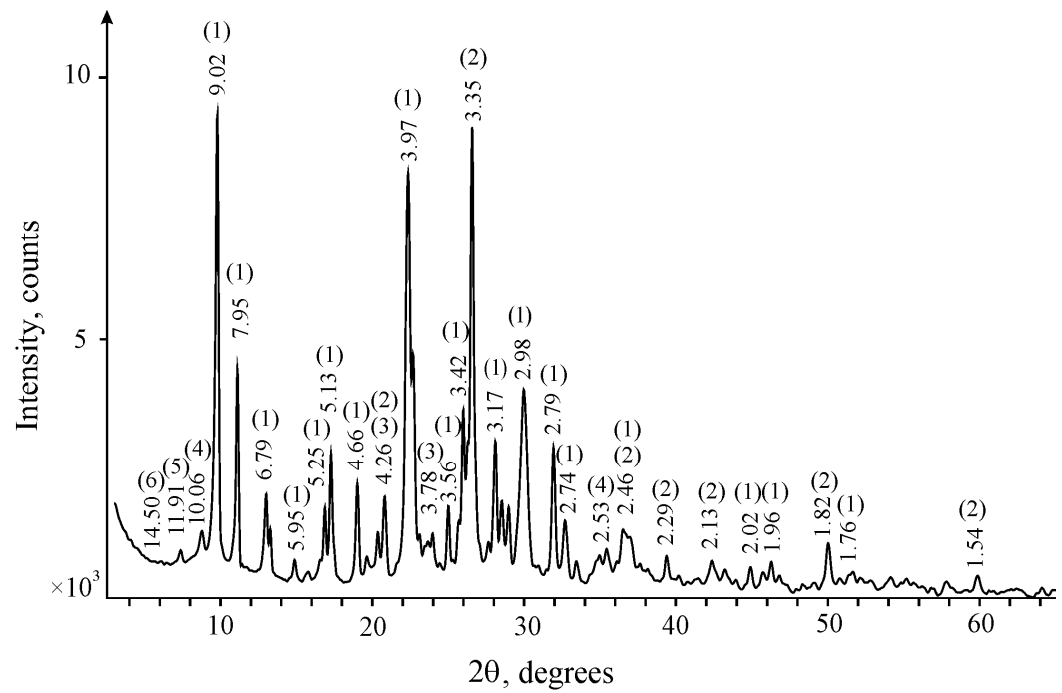

Figure 1. X-ray diffraction pattern of the zeolite sample. (1) zeolites, (2) quartz, (3) microcline, (4) illite, (5) sepiolite, and (6) smectite.

Table 1. Chemical composition of zeolite sample, according to data of X-ray fluorescence analysis.

\begin{tabular}{cccc}
\hline Compound Formula & Concentration (\%) & Compound Formula & Concentration (\%) \\
\hline $\mathrm{SiO}_{2}$ & 78.165 & $\mathrm{SrO}$ & 0.053 \\
$\mathrm{Al}_{2} \mathrm{O}_{3}$ & 11.530 & $\mathrm{MnO}$ & 0.050 \\
$\mathrm{Na}_{2} \mathrm{O}$ & 3.012 & $\mathrm{P}_{2} \mathrm{O}_{5}$ & 0.039 \\
$\mathrm{~K}_{2} \mathrm{O}$ & 2.232 & $\mathrm{Rb}_{2} \mathrm{O}$ & 0.022 \\
$\mathrm{MgO}$ & 2.054 & $\mathrm{BaO}$ & 0.015 \\
$\mathrm{CaO}$ & 1.622 & $\mathrm{ZrO}$ & 0.009 \\
$\mathrm{Fe}_{2} \mathrm{O}_{3}$ & 0.984 & $\mathrm{Y}_{2} \mathrm{O}_{3}$ & 0.001 \\
$\mathrm{TiO}_{2}$ & 0.212 & Total & 100.000 \\
\hline
\end{tabular}

\subsection{Mechanical and Thermal Stability of the Magnesium Potassium Phosphate Compound}

Data on the optimal zeolite filling of the MKP compound samples were given in Table 2. It was found that the compressive strength of the compound increases with the addition of zeolite in the composition of the samples (Table 2), while the strength does not increase with the injection of zeolite more than $4.2 \mathrm{wt} \%$. Clearly, this amount of zeolite fills the pores in the MKP compound, which make up about $5 \mathrm{vol} \%[4]$.

Table 2. Effect of zeolite on the compressive strength of the magnesium potassium phosphate (MKP) compound.

\begin{tabular}{cc}
\hline Zeolite Content (wt \%) & Compressive Strength (MPa) \\
\hline 0 & $12.0 \pm 3.0$ \\
4.2 & $23.8 \pm 1.7$ \\
16.7 & $26.6 \pm 4.0$ \\
23.0 & $22.3 \pm 2.0$ \\
28.6 & $25.6 \pm 3.4$ \\
\hline
\end{tabular}

It was noted that after holding the compounds at $450{ }^{\circ} \mathrm{C}$ for $4 \mathrm{~h}$, the samples lost their compressive strength, with the exception of samples containing at least $28.6 \mathrm{wt} \%$ zeolite (compressive strength was $9.7 \pm 0.5 \mathrm{MPa}$ ). The obtained values for the compressive strength of the samples meet the requirements for vitrified HLW (at least 9.0 MPa) [14]. It is likely that zeolite under significant content in the compound exhibits reinforcing properties, which allows the maintenance of the strength of the compound at the required level. It should be noted that the effect of increasing the strength of the 
cement compound with an optimal content of about $30 \%$ zeolite was previously shown [29]. Thus, the MKP compound containing $28.6 \mathrm{wt} \%$ zeolite was selected to study hydrolytic stability.

\subsection{Hydrolytic Stability of the Magnesium Potassium Phosphate Compound}

The specific activity of the radionuclides in the compound is presented in Table 3. The content of the HLW surrogate in the compound samples was about $31.6 \mathrm{wt} \%$.

Table 3. Characteristic of the MKP with zeolite (MKPZ) compound prepared under study.

\begin{tabular}{cc}
\hline Radionuclide & Specific Activity (Bq/g) \\
\hline${ }^{137} \mathrm{Cs}$ & $1.7 \times 10^{4}$ \\
${ }^{90} \mathrm{Sr}$ & $1.5 \times 10^{4}$ \\
${ }^{239} \mathrm{Pu}$ & $6.8 \times 10^{4}$ \\
${ }^{241} \mathrm{Am}$ & $9.3 \times 10^{3}$ \\
\hline
\end{tabular}

Samples of the MKP compound obtained by solidification of the HLW surrogate with the addition of zeolite (MKPZ), and after heat treatment of the compound at $120^{\circ} \mathrm{C}$ (MKPZ_term), were used to study hydrolytic stability.

The leaching degree $(E)$, differential $\left(L R_{\text {dif }}\right)$ and integral $\left(L R_{\text {int }}\right)$ leaching rate of radionuclides from the synthesized compound were determined in accordance with standards [30]. The kinetic curves of the radionuclide $L R_{\text {dif }}$ from the MKP compounds are shown in Figure $2 \mathrm{a}-\mathrm{d}$, and the $\mathrm{E}$ and $L R_{\text {int }}$ are presented in Table 4. To compare the hydrolytic stability of the compounds, the curves of the radionuclides $L R_{d i f}$ from the MKP compounds not containing zeolite are also shown in Figure 2a-d.

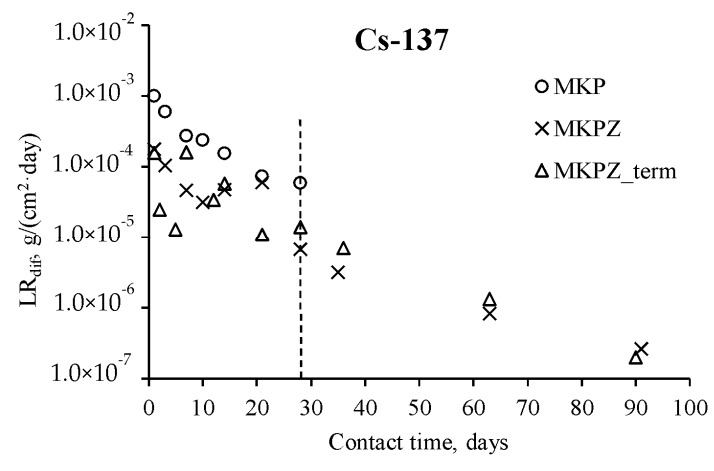

(a)

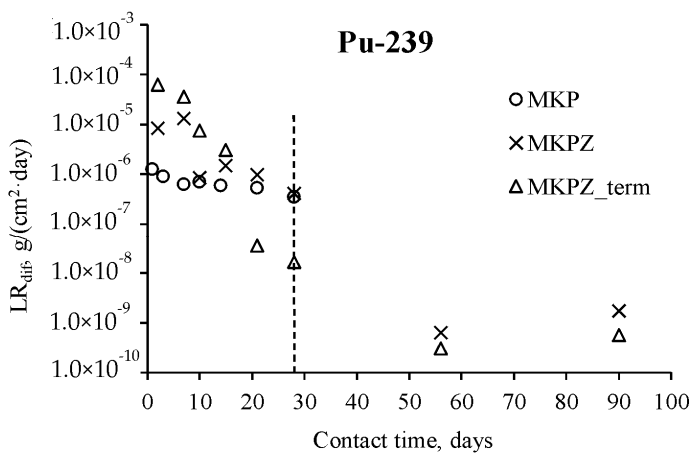

(c)

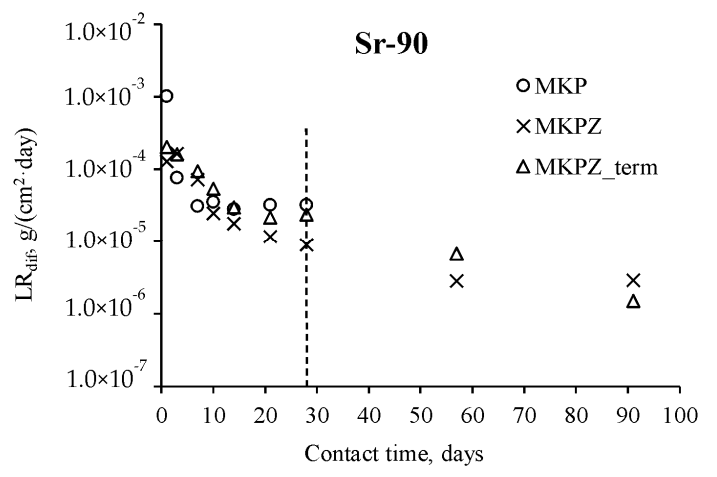

(b)

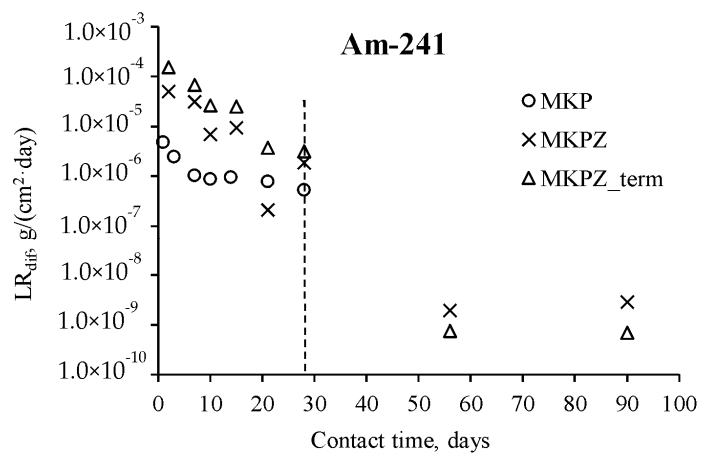

(d)

Figure 2. Kinetic curves of the radionuclides leaching from the MKP compound not containing zeolite (MKP) and containing zeolite (MKPZ), including after heat treatment of the MKPZ compound (MKPZ_term): ${ }^{137} \mathrm{Cs}(\mathbf{a}),{ }^{90} \mathrm{Sr}(\mathbf{b}),{ }^{239} \mathrm{Pu}(\mathbf{c}),{ }^{241} \mathrm{Am}(\mathbf{d})$. 
Table 4. Integral leaching rate $\left(L R_{\text {int }}\right)$ and leaching degree $(E)$ of radionuclides from the MKPZ compound, according to standard [30], on the 90th day of contact with water.

\begin{tabular}{cccc}
\hline Radionuclide & Compound & $\mathbf{L R}_{\text {int }}\left(\mathrm{g} /\left(\mathbf{c m}^{2} \cdot\right.\right.$ day $\left.)\right)$ & $\boldsymbol{E} \mathbf{( \% )}$ \\
\hline \multirow{2}{*}{${ }^{137} \mathrm{Cs}$} & MKPZ & $1.5 \times 10^{-5}$ & 0.22 \\
& MKPZ_term & $1.2 \times 10^{-5}$ & 0.22 \\
\hline \multirow{2}{*}{${ }^{90} \mathrm{Sr}$} & MKPZ & $1.3 \times 10^{-5}$ & 0.19 \\
& MKPZ_term & $1.9 \times 10^{-5}$ & 0.34 \\
\hline \multirow{2}{*}{${ }^{239} \mathrm{Pu}$} & MKPZ & $1.1 \times 10^{-6}$ & 0.02 \\
& MKPZ_term & $3.8 \times 10^{-6}$ & 0.07 \\
\hline \multirow{2}{*}{${ }^{241} \mathrm{Am}$} & MKPZ & $3.8 \times 10^{-6}$ & 0.05 \\
& MKPZ_term & $1.0 \times 10^{-5}$ & 0.18 \\
\hline
\end{tabular}

Previously, it was found that the differential leaching rate of ${ }^{239} \mathrm{Pu}$ and ${ }^{241} \mathrm{Am}$ from the MKP compound not containing zeolite on the 28th day of contact with water is $3.5 \times 10^{-7}$ and $5.3 \times 10^{-7} \mathrm{~g} /\left(\mathrm{cm}^{2}\right.$.day), respectively (Figure $2 \mathrm{c}, \mathrm{d}$ ) [11], while for ${ }^{137} \mathrm{Cs}$ and ${ }^{90} \mathrm{Sr}$ it is $5.8 \times 10^{-5}$ and $3.2 \times 10^{-5} \mathrm{~g} /\left(\mathrm{cm}^{2}\right.$.day), respectively (Figure $\left.2 \mathrm{a}, \mathrm{b}\right)$, in the present work.

It was shown that adding zeolite to the composition of the compound increases hydrolytic stability, while the leaching rate of ${ }^{137} \mathrm{Cs}$ decreases by one order of values (Figure 2a), and that of ${ }^{90} \mathrm{Sr}$ by four times (Figure $2 b$ ). The effect of zeolite on the leaching of ${ }^{239} \mathrm{Pu}$ and ${ }^{241} \mathrm{Am}$ is insignificant (Figure $2 \mathrm{c}, \mathrm{d}$ ), and the leaching of these radionuclides is at a low level. The differential leaching rate of radionuclides from the compounds containing $28.6 \mathrm{wt} \%$ zeolite on the 90th day of contact with water was $2.6 \times 10^{-7}$ for ${ }^{137} \mathrm{Cs}, 2.9 \times 10^{-6}$ for ${ }^{90} \mathrm{Sr}, 1.7 \times 10^{-9}$ for ${ }^{239} \mathrm{Pu}$, and $2.9 \times 10^{-9} \mathrm{~g} /\left(\mathrm{cm}^{2}\right.$.day) for ${ }^{241} \mathrm{Am}$. It should be noted that the leaching rate of radionuclides on the 90th day does not change, even after heat treatment of the compounds at $120^{\circ} \mathrm{C}$ (Figure 2, Table 4). Thus, the hydrolytic stability of the MKP compound corresponds to the requirements of glass-like compound application for HLW immobilization [14] in Russia (according to the requirements, the leaching rate of ${ }^{137} \mathrm{Cs},{ }^{90} \mathrm{Sr}$, and ${ }^{239} \mathrm{Pu}$ is $\leq 1.0 \times 10^{-5}$, $1.0 \times 10^{-6}$, and $1.0 \times 10^{-7} \mathrm{~g} /\left(\mathrm{cm}^{2} \cdot\right.$ day $)$, respectively).

\section{Materials and Methods}

\subsection{Chemicals and Procedures}

The experiments were performed in the glove box (Pererabotka, Dzerzhinsk, Nizhny Novgorod region, Russia) at ambient atmospheric conditions. The chemicals used in the experiments were of no less than chemically pure grade.

The samples of the MKP compound were prepared at room temperature by solidification of the industrial HLW surrogate, obtained after the SNF reprocessing of the WWER-1000, according to the procedure previously given [12]. The HLW surrogate was prepared by dissolving the metal nitrates in an aqueous solution of nitric acid; nuclides were added to the HLW surrogate individually. The content of $\mathrm{HNO}_{3}$ in the $\mathrm{HLW}$ surrogate was $3.2 \mathrm{~mol} / \mathrm{L}$, and the density was about $1.21 \mathrm{~kg} / \mathrm{L}$. Preliminary preparation of the HLW surrogate and binding components $\left(\mathrm{MgO}, \mathrm{KH}_{2} \mathrm{PO}_{4}\right)$ was previously reported [11,31]. The chemical and radionuclide composition of the prepared HLW surrogate is presented in Table 5. The density of the HLW surrogate is $1280 \mathrm{~g} / \mathrm{L}$, the $\mathrm{pH}$ was $7.0 \pm 0.1$, and the salt content was about $484 \mathrm{~g} / \mathrm{L}$.

Table 5. Radionuclide and chemical composition of the prepared high-level waste (HLW) surrogate.

\begin{tabular}{cc}
\hline Specific Activity of Actinides (Bq/L) & Metal Content (g/L) \\
\hline${ }^{239} \mathrm{Pu}: 2.8 \times 10^{8}$ & $\mathrm{Na}-83.9 ; \mathrm{Sr}-3.0 ; \mathrm{Zr}-5.6 ; \mathrm{Mo}-0.8 ;$ \\
${ }^{241} \mathrm{Am}: 3.8 \times 10^{7}$ & $\mathrm{Pd}-4.1 ; \mathrm{Cs}-7.4 ; \mathrm{Ba}-1.2 ; \mathrm{Nd}-28.2 ;$ \\
${ }^{137} \mathrm{Cs}: 7.1 \times 10^{7}$ & $\mathrm{Fe}-0.8 ; \mathrm{Cr}-2.3 ; \mathrm{Ni}-0.4 ; \mathrm{U}-2.1$ \\
${ }^{90} \mathrm{Sr}: 5.8 \times 10^{7}$ & \\
\hline
\end{tabular}


The natural zeolite of the Sokyrnytsya deposit of the Transcarpathian region (ZEO-MAX LLC, Russia), with a particle size of $0.07-0.16 \mathrm{~mm}$ and a specific surface area of $17.5 \mathrm{~m}^{2} / \mathrm{g}$, was used as a mineral modifier.

As a result, cubic samples of the MKP compound with dimensions of $2 \mathrm{~cm} \times 2 \mathrm{~cm} \times 2 \mathrm{~cm}$ were prepared. The samples were kept for at least 15 days at ambient atmospheric conditions.

\subsection{Methods}

The mineral composition of zeolite was calculated using the powder X-ray diffraction (XRD) method (Ultima-IV, Rigaku, Tokyo, Japan). The X-ray diffraction data were interpreted using the specialized Jade 6.5 program package (MDI, Livermore, CA, USA), with the PDF-2 powder database. The mineral composition was determined using the Rietveld method [32], with a PROFEX GUI software package for BGMN [33]. The elemental composition of the zeolite was studied using an X-ray fluorescence spectrometer (Axious Advanced PW 4400/04, PANalytical B.V., Netherlands).

The compressive strength of the obtained compounds was determined using a universal test machine AG-X Plus (Shimadzu, Japan), in accordance with GOST 310.4-81 [34].

Thermal stability of the obtained compounds was studied after heat treatment to constant weight, both at $120{ }^{\circ} \mathrm{C}$ during $24 \mathrm{~h}$ (heating rate $4{ }^{\circ} \mathrm{C} / \mathrm{min}$ ), for quantitative removal of the bound water from the compounds (as previously shown in reference [35]), and at $450{ }^{\circ} \mathrm{C}$ during $4 \mathrm{~h}$ (heating rate $7^{\circ} \mathrm{C} / \mathrm{min}$ ), in accordance with the current requirements for solidified HLW [14]. Compound samples were heat-treated in the muffle furnace (SNOL 30/1300, AB UMEGA GROUP, Utena, Lithuania); cooling of the samples occurred in a non-functioning furnace with its direct cooling.

The initial compounds and the samples after removal of the bound water were tested for hydrolytic stability. The hydrolytic stability of compounds was determined using the semidynamic test, in accordance with GOST R 52126-2003 [30]. The conditions were as follows: monolithic compound, a leaching agent of bi-distilled water ( $\mathrm{pH} 6.6 \pm 0.1$, volume $200 \mathrm{~mL})$, and temperature at $25 \pm 3{ }^{\circ} \mathrm{C}$. Periodic replacement of the leaching agent was proceeded after 1, 3, 7, 10, 14, etc. days, with the total duration of the test up to 90 days ( 28 days for compounds not containing zeolite). The content of radionuclides in solutions after leaching was determined by radiometric methods ( $\alpha$ - and $\gamma$-ray spectrometers; Canberra, Meriden, CT, USA, and a $\alpha-\beta$ radiometer UMF 2000, LLC RPE «Doza», Zelenograd, Moscow, Russia). The calculation procedure of the differential $\left(L R_{d i f}\right)$ and integral $\left(L R_{\text {int }}\right)$ leaching rates of radionuclides from samples is given in [31].

\section{Conclusions}

As a result of the study, it is shown that the use of zeolite from Sokyrnytsya deposit as a mineral modifier can increase the mechanical strength (two times), as well as the thermal (up to $450{ }^{\circ} \mathrm{C}$ ) and hydrolytic resistance to leaching of HLW radionuclides (the leaching rate of ${ }^{137} \mathrm{Cs}$ decreases by one order of values, and ${ }^{90} \mathrm{Sr}$ by four times). These conclusions are explained by the properties of zeolites, which have reinforcing properties and high adsorption ability to radionuclides (especially cesium). Thus, the MKP compound containing such zeolite can be recommended to radiochemical plants as a new material for HLW immobilization.

Author Contributions: S.A.K. performed the study, analyzed and interpreted the data, and wrote the manuscript. S.E.V. proposed the study concept, supervised the study, analyzed and interpreted the data, and edited the manuscript.

Funding: The zeolite composition determination was carried out in the framework of the state assignment of the Vernadsky Institute of Geochemistry and Analytical Chemistry of Russian Academy of Sciences, and the study of the properties of compounds is due to a grant from the Russian Science Foundation (project no. 16-13-10539).

Acknowledgments: The mineral composition of the zeolite was determined by Krupskaya V.V. and Morozov I.A. (Lomonosov Moscow State University; Institute of Geology of Ore Deposits, Petrography, Mineralogy and Geochemistry of Russian Academy of Sciences), using an Ultima-IV X-ray diffractometer (Rigaku) purchased within the framework of implementation of the Development Program of the Lomonosov Moscow State University. 
Conflicts of Interest: The authors declare no conflict of interest. The funders had no role in the design of the study; in the collection, analyses, or interpretation of data; in the writing of the manuscript, or in the decision to publish the results.

\section{References}

1. Ojovan, M.I.; Lee, W.E.; Kalmykov, S.N. An Introduction to Nuclear Waste Immobilisation, 3rd ed.; Elsevier: Amsterdam, The Netherlands, 2019; pp. 1-512. ISBN 978-0-08-102702-8. [CrossRef]

2. Stefanovsky, S.V.; Yudintsev, S.V.; Vinokurov, S.E.; Myasoedov, B.F. Chemical-technological and mineralogical-geochemical aspects of the radioactive waste management. Geochem. Int. 2016, 54, 1136-1156. [CrossRef]

3. Graeser, S.; Postl, W.; Bojar, H.-P.; Berlepsch, P.; Armbruster, T.; Raber, T.; Ettinger, K.; Walter, F. Struvite-(K), $\mathrm{KMgPO}_{4} \cdot 6 \mathrm{H}_{2} \mathrm{O}$, the potassium equivalent of struvite-A new mineral. Eur. J. Miner. 2008, 20, 629-633. [CrossRef]

4. Wagh, A.S. Chemically Bonded Phosphate Ceramics: Twenty-First Century Materials with Diverse Applications, 2nd ed.; Elsevier: Amsterdam, The Netherlands, 2016; pp. 1-422. ISBN 978-0-08-100380-0.

5. Singh, D.; Mandalika, V.R.; Parulekar, S.J.; Wagh, A.S. Magnesium potassium phosphate ceramic for ${ }^{99} \mathrm{Tc}$ immobilization. J. Nucl. Mater. 2006, 348, 272-282. [CrossRef]

6. Wagh, A.S.; Strain, R.; Jeong, S.Y.; Reed, D.; Kraus, T.; Singh, D. Stabilization of Rocky Flats Pu-contaminated ash within chemically bonded phosphate ceramics. J. Nucl. Mater. 1999, 265, 295-307. [CrossRef]

7. Zhenyu, L.; Hongtao, W.; Yang, H.; Tao, Y.; Zhongyuan, L.; Shuzhen, L.; Haibin, Z. Rapid solidification of Highly Loaded High-Level Liquid Wastes with magnesium phosphate cement. Ceram. Int. 2019, 45, 5050-5057. [CrossRef]

8. Shkuropatenko, V.A. High level wastes immobilization in ceramic and hydrated phosphate matrix. East Eur. J. Phys. 2016, 3, 49-60.

9. Vinokurov, S.E.; Kulyako, Y.M.; Slyunchev, O.M.; Rovny, S.I.; Myasoedov, B.F. Low-temperature immobilization of actinides and other components of high-level waste in magnesium potassium phosphate matrices. J. Nucl. Mater. 2009, 385, 189-192. [CrossRef]

10. Vinokurov, S.E.; Kulyako, Y.M.; Slyunchev, O.M.; Rovnyi, S.I.; Wagh, A.S.; Maloney, M.D.; Myasoedov, B.F. Magnesium potassium phosphate matrices for immobilization of high-level liquid wastes. Radiochemistry 2009, 51, 65-72. [CrossRef]

11. Vinokurov, S.E.; Kulikova, S.A.; Myasoedov, B.F. Magnesium Potassium Phosphate Compound for Immobilization of Radioactive Waste Containing Actinide and Rare Earth Elements. Materials 2018, 11, 976. [CrossRef] [PubMed]

12. Vinokurov, S.E.; Kulikova, S.A.; Myasoedov, B.F. Solidification of high level waste using magnesium potassium phosphate compound. Nucl. Eng. Technol. 2019, 51, 755-760. [CrossRef]

13. Vinokurov, S.E.; Kulikova, S.A.; Myasoedov, B.F. Hydrolytic and thermal stability of magnesium potassium phosphate compound for immobilization of high level waste. J. Radioanal. Nucl. Chem. 2018, 318, 2401-2405. [CrossRef]

14. Federal Norms and Rules in the Field of Atomic Energy Use "Collection, Processing, Storage and Conditioning of Liquid Radioactive Waste. Safety Requirements" (NP-019-15). Rostekhnadzor, Russia, 2015; 1-22.

15. Sayenko, S.Y.; Shkuropatenko, V.A.; Dikiy, N.P.; Tarasov, R.V.; Ulybkina, K.A.; Surkov, O.Y.; Litvinenko, L.M. Clinoptilolite with cesium immobilization to potassium magnesium phosphate matrix. East Eur. J. Phys. 2017, 4, 37-43. [CrossRef]

16. Kuenzel, C.; Cisneros, J.F.; Neville, T.P.; Vandeperre, L.J.; Simons, S.J.R.; Bensted, J.; Cheeseman, C.R. Encapsulation of $\mathrm{Cs} / \mathrm{Sr}$ contaminated clinoptilolite in geopolymers produced from metakaolin. J. Nucl. Mater. 2015, 466, 94-99. [CrossRef]

17. Munthali, M.W.; Johan, E.; Aono, H.; Matsue, N. Cs ${ }^{+}$and $\mathrm{Sr}^{2+}$ adsorption selectivity of zeolites in relation to radioactive decontamination. J. Asian Ceram. Soc. 2015, 3, 245-250. [CrossRef]

18. Borai, E.H.; Harjula, R.; Malinen, L.; Paajanen, A. Efficient removal of cesium from low-level radioactive liquid waste using natural and impregnated zeolite minerals. J. Hazard. Mater. 2009, 172, 416-422. [CrossRef]

19. Plecas, I.; Dimovic, S.; Smiciklas, I. Influence of bentonite and zeolite in cementation of dry radioactive evaporator concentrates. Appl. Clay Sci. 2009, 43, 9-12. [CrossRef] 
20. Tyupina, E.A.; Sazonov, A.B.; Sergeecheva, Y.V.; Shestakov, I.A.; Tuchkova, A.I.; Nikitin, A.V. Application of thermally expanded graphite for the cementation of cesium and tritium containing waste oils. Inorg. Mater. Appl. Res. 2016, 7, 196-203. [CrossRef]

21. Woszuk, A.; Franus, W. A review of the application of zeolite materials in Warm Mix Asphalt technologies. Appl. Sci. 2019, 7, 293. [CrossRef]

22. Misaelides, P. Clay minerals and zeolites for radioactive waste immobilization and containment: A concise overview. In Modified Clay and Zeolite Nanocomposite Materials; Mercurio, M., Sarkar, B., Langella, A., Eds.; Elsevier: Amsterdam, The Netherlands, 2019; pp. 243-274, ISBN 978-0-12-814617-0. [CrossRef]

23. Xu, Z.; Jiang, Z.; Wu, D.; Peng, X.; Xu, Y.; Li, N.; Qi, Y.; Li, P. Immobilization of strontium-loaded zeolite A by metakaolin based-geopolymer. Ceram. Int. in press. [CrossRef]

24. Suna, Q.; Li, J.; Wanga, J. Solidification of borate radioactive resins using sulfoaluminate cement blending with zeolite. Nucl. Eng. Des. 2011, 241, 5308-5315. [CrossRef]

25. Juoi, J.M.; Ojovan, M.I.; Lee, W.E. Microstructure and leaching durability of glass composite wasteforms for spent clinoptilolite immobilization. J. Nucl. Mater. 2008, 372, 358-366. [CrossRef]

26. Kimura, R.; Inagaki, Y.; Idemitsu, K.; Arima, T. Vitrification processes of simulated cesium sorbing zeolite waste. Prog. Nucl. Energy 2018, 108, 497-502. [CrossRef]

27. Woszuk, A.; Franus, W. Properties of the Warm Mix Asphalt involving clinoptilolite and Na-P1 zeolite additives. Constr. Build. Mater. 2016, 114, 556-563. [CrossRef]

28. Markin, T.; Sobol, K.; Franus, M.; Franus, W. Mechanical and durability properties of concretes incorporating natural zeolite. Arch. Civ. Mech. Eng. 2016, 16, 554-562. [CrossRef]

29. Mola-Abasi, H.; Shooshpasha, I. Influence of zeolite and cement additions on mechanical behavior of sandy soil. J. Rock Mech. Geotech. Eng. 2016, 8, 746-752. [CrossRef]

30. GOST R 52126-2003. Radioactive Waste. Long Time Leach Testing of Solidified Radioactive Waste Forms; Gosstandart: Moscow, Russia, 2003; pp. 1-8.

31. Vinokurov, S.E.; Kulikova, S.A.; Krupskaya, V.V.; Danilov, S.S.; Gromyak, I.N.; Myasoedov, B.F. Investigation of the leaching behavior of components of the magnesium potassium phosphate matrix after high salt radioactive waste immobilization. J. Radioanal. Nucl. Chem. 2018, 315, 481-486. [CrossRef]

32. Post, J.E.; Bish, D.L. Rietveld refinement of crystal structures using powder X-ray diffraction data. In Modern Powder Diffraction; Bish, D.L., Post, J.E., Eds.; De Gruyter: Berlin, Germany, 1989; pp. 277-308, ISBN 978-1-5015-0901-8. [CrossRef]

33. Doebelin, N.; Kleeberg, R. Profex: A graphical user interface for the Rietveld refinement program BGMN. J. Appl. Crystallogr. 2015, 48, 1573-1580. [CrossRef]

34. GOST 310.4-81. Cements. Methods of Bending and Compression Strength Determination; INTERSTATE STANDARD, Gosstroy 151: Moscow, Russia, 1981; pp. 1-11.

35. Vinokurov, S.E.; Kulikova, S.A.; Krupskaya, V.V.; Myasoedov, B.F. Magnesium Potassium Phosphate Compound for Radioactive Waste Immobilization: Phase Composition, Structure, and Physicochemical and Hydrolytic Durability. Radiochemistry 2018, 60, 70-78. [CrossRef]

Sample Availability: Samples of the compounds are available from the authors.

(C) 2019 by the authors. Licensee MDPI, Basel, Switzerland. This article is an open access article distributed under the terms and conditions of the Creative Commons Attribution (CC BY) license (http://creativecommons.org/licenses/by/4.0/). 